\title{
Fecundity, growth, and survival of the angelfish Pterophyllum scalare (Perciformes: Cichlidae) under laboratory conditions
}

\author{
Armando A. Ortega-Salas ${ }^{1 *}$, Isabel Cortés G. ${ }^{2} \&$ Hugo Reyes-Bustamante ${ }^{1}$ \\ 1. Instituto de Ciencias del Mar y Limnología, UNAM. Calzada Joel Montes Camarena s/n Apdo. Post. 811, Mazatlán, \\ 82040 Sinaloa, México; ortsal@mar.icmyl.unam.mx \\ 2. Depto. de Investigaciones Científicas y Tecnológicas, Universidad de Sonora, Rosales y Niños Héroes s/n, Col. \\ Centro, Apdo. Postal 1819, Hermosillo 83000, Sonora, México. \\ * Corresponding author
}

Received 17-X-2006. Corrected 05-IV-2009. Accepted 07-V-2009.

\begin{abstract}
The freshwater angelfishes (Pterophyllum) are South American cichlids that have become very popular among aquarists, yet scarce information on their culture and aquarium husbandry exists. We studied Pterophyllum scalare to analyze dietary effects on fecundity, growth, and survival of eggs and larvae during 135 days. Three diets were used: A) decapsulated cysts of Artemia, B) commercial dry fish food, and C) a mix diet of the rotifer Brachionus plicatilis and the cladoceran Daphnia magna. The initial larval density was 100 organisms in each $40 \mathrm{~L}$ aquarium. With diet A, larvae reached a maximum weight of $3.80 \mathrm{~g}$, a total length of 6.3 $\mathrm{cm}$, and a height of $5.8 \mathrm{~cm}$; with diet B: $2.80 \mathrm{~g}, 4.81 \mathrm{~cm}$, and $4.79 \mathrm{~cm}$, and with diet C: $3.00 \mathrm{~g}, 5.15 \mathrm{~cm}$, and $5.10 \mathrm{~cm}$, respectively. Significant differences were observed between diet A, and diet B and C, but no significantly differences were observed between diets B and C. Fecundity varied from 234 to 1082 eggs in 20 and $50 \mathrm{~g}$ females, respectively. Egg survival ranged from $87.4 \%$ up to $100 \%$, and larvae survival ( 80 larvae/40L aquarium) from $50 \%$ to $66.3 \%$ using diet B and A, respectively. Live food was better for growing fish than the commercial balanced food diet. Fecundity and survival are important factors in planning a good production of angelfish. Rev. Biol. Trop. 57 (3): 741-747. Epub 2009 September 30.
\end{abstract}

Key words: angelfish, Pterophyllum scalare (Perciformes: Cichlidae), culture, fecundity, growth, survival.

The freshwater angelfishes (Pterophyllum) are South American cichlids that originate from the Guyana, and the Orinoco and Amazon River basins. In the wild, their reproductive season is around January, at a water temperature between 28 and $30^{\circ} \mathrm{C}$. Angelfishes are very popular among aquarists all over the world, yet scarce information on their culture and aquarium husbandry exists (Axelrod \& Shaw 1967, Pérez 1984), and little has been reported regarding scientific measurements of its growth and fecundity (Martty 1977).

Nutrition has an important influence on growth and reproductive potential of aquarium fishes, and live foods are often advocated as a means to enhance these factors. For example, Reyes-Bustamante (1999), studying the goldfish (Carassius auratus), fighting fish (Betta splendens) and gourami (Trichogaster trichopterus), showed that juvenile fish raised on live rotifera (Brachionus plicatilis) and the cladoceran (Daphnia magna) yielded better growth than those fed with two different formulations of commercial dry fish food.

Similar nutritional studies using live foods have been documented for angelfish. For example, Figueroa et al. (1977) found that angelfish fed exclusively with $D$. pulex produced larger and more frequent spawnings with greater fry survival than those fed exclusively on a commercial dry flake. 
The aim of this study was to quantify fecundity, growth, and survival of eggs and larvae of angelfish cultured under laboratory conditions, and using two different live food diets and one commercial dry diet.

\section{MATERIALS AND METHODS}

The study was performed under laboratory conditions at the Autonomous University of Sinaloa in Mazatlán, Sinaloa, Mexico.

Fish: Mature angelfish, 9 to 10 months old, were used for the study. These fish were second generation stock that had been bred on site (Table 1).
Water conditions: Throughout the study, fish were maintained under the following water parameters: temperature 24.3 to $30^{\circ} \mathrm{C} ; \mathrm{pH}$ 7.8 to 9.0. Water quality was maintained by bio-filtration and total water changes were performed every 15 days, after the first 30 days (weaning).

Spawning conditions: Fish were settled in an $80 \mathrm{~L}$ aquarium, and allowed to pair naturally. Each formed pair was transferred to its own aquarium containing a plastic plate positioned diagonally, to serve as a spawning surface. After spawning, the eggs were reared artificially. The plastic plate with the eggs attached was transferred to another aquarium and an air

TABLE 1

Measurements of Pterophyllum scalare and its relation with fecundity and eggs survival

CUADRO 1

Medidas del Pterophyllum scalare y su relación con fecundidad y supervivencia de huevos

\begin{tabular}{|c|c|c|c|c|c|c|c|}
\hline Female & $\begin{array}{l}\text { Number } \\
\text { of eggs }\end{array}$ & $\begin{array}{l}\text { Weight } \\
\text { (g) }\end{array}$ & $\begin{array}{l}\text { Length } \\
\text { (cm) }\end{array}$ & $\begin{array}{l}\text { Height } \\
(\mathrm{cm})\end{array}$ & Live eggs & $\begin{array}{l}\text { Fertilization rate } \\
\text { from live eggs }\end{array}$ & $\begin{array}{l}\text { Relative } \\
\text { Fecundity }\end{array}$ \\
\hline 1 & 530 & 32 & 16.5 & 20.0 & 463 & 87.36 & 16.56 \\
\hline 2 & 332 & 25 & 17.0 & 23.7 & 332 & 100 & 13.28 \\
\hline 3 & 1082 & 50 & 22.0 & 28.8 & 1028 & 95.01 & 21.64 \\
\hline 4 & 297 & 18 & 12.5 & 13.0 & 271 & 91.25 & 16.50 \\
\hline 5 & 417 & 27 & 17.0 & 20.0 & 415 & 99.52 & 15.44 \\
\hline 6 & 234 & 20 & 12.5 & 15.0 & 228 & 97.44 & 11.70 \\
\hline 7 & 445 & 32 & 16.5 & 20.0 & 410 & 92.13 & 13.91 \\
\hline 8 & 421 & 25 & 17.0 & 23.7 & 415 & 98.57 & 16.84 \\
\hline 9 & 403 & 27 & 17.0 & 20.0 & 400 & 98.26 & 14.93 \\
\hline 10 & 506 & 27 & 17.0 & 20.0 & 498 & 98.42 & 18.74 \\
\hline 11 & 462 & 32 & 16.5 & 20.0 & 417 & 90.26 & 14.44 \\
\hline 12 & 413 & 25 & 17.0 & 23.7 & 410 & 99.27 & 16.52 \\
\hline 13 & 868 & 50 & 22.0 & 28.8 & 837 & 96.43 & 17.36 \\
\hline 14 & 385 & 18 & 12.5 & 12.5 & 359 & 93.25 & 21.39 \\
\hline 15 & 309 & 27 & 17.0 & 20.0 & 301 & 97.41 & 11.44 \\
\hline 16 & 374 & 20 & 12.5 & 15.0 & 370 & 98.93 & 18.70 \\
\hline 17 & 518 & 32 & 16.5 & 20.0 & 512 & 98.84 & 16.19 \\
\hline 18 & 364 & 25 & 17.0 & 23.7 & 350 & 96.15 & 14.56 \\
\hline 19 & 505 & 27 & 17.0 & 20.0 & 485 & 96.04 & 18.70 \\
\hline 20 & 511 & 27 & 17.0 & 20.0 & 500 & 97.85 & 18.93 \\
\hline Mean & 468.8 & 28.3 & 16.5 & 20.4 & 450 & 96.11 & 16.4 \\
\hline $\mathrm{SD}$ & 193.9 & 8.58 & 2.58 & 4.36 & 184.2 & 3.51 & 2.79 \\
\hline SE & 43.3 & 1.9 & 0.57 & 0.97 & 41.2 & 0.78 & 0.62 \\
\hline
\end{tabular}


supply was placed near the egg clutch to create water movement and aeration.

Measurements: Data was registered from 20 spawnings. The eggs within each clutch were counted (number of eggs), then the mother fish was measured (length $\mathrm{mm}$ and height $\mathrm{mm}$ ), and weighed (weight g) to obtain the relative fecundity: $E n=z / W$, where $E n=n u m b e r$ of eggs per weight $(\mathrm{g})$ of fish; $\mathrm{z}=$ number of eggs; $W=$ total weight of fish. The rate of fecundity for weight was calculated using the regression line, Number of eggs $=\mathrm{a}+\mathrm{b}(\mathrm{W})$, where W: total weight, a: y-intercept, b: slope. Additionally, live larvae were counted to obtain the fertilization rate: live eggs/number of eggs x 100 (Table 1).

Rearing diets: Three different diets were used during 135 days to calculate the growth in length and height of 100 larvae in 40L aquariums.

Diet A: Decapsulated cysts of Artemia sp. were used to feed angelfish larvae once a day at a rate of 4 cysts $/ \mathrm{mL}$ for 10 days, thereafter a rate of 6 cysts $/ \mathrm{mL}$ was used until the end of the study. The fish eat ad libitum.

Diet B: Small flakes of "Tetramin" balanced food to fit the size of the mouth were given at about $6 \%$ to the fish biomass in three rations per day.

Diet C: Once the vitellarium sac had been absorbed, rotifers, Brachionus_plicatilis, were given at a rate of $10 / \mathrm{mL}$ for 10 days; thereafter, 2 cladocerans $D$. magna $7 / \mathrm{mL}$ were given three times per day until the end of the study. The fish eat ad libitum.

To calculate growth an average of ten fish were used every 15 days. The length $(\mathrm{cm})$ and height $(\mathrm{cm})$ of angelfish larvae samples were first measured using a hematocytometer under a stereoscopic microscope. Later, when the larvae reached more than $5 \mathrm{~mm}$ in length, a petri dish with millimetric paper was used. Fry wet weight was measured with an Ohaus 480 scale balance $(0.001 \mathrm{~g})$ using the difference between a known water volume and one with fry.

Also, during 135 days (November 1st to March $15^{\text {th }}$ ), using the three different diets mentioned before, the instantaneous total mortality rate $(\mathrm{Z})$ was estimated for 80 larvae/40 L aquarium through the Beverton \& Holt (1959) method and described in Ricker (1975), $\mathrm{Nt}=\mathrm{N}_{0}$ $\mathrm{e}-\mathrm{Z} \mathrm{t}$, where $\mathrm{N}_{0}$ and $\mathrm{Nt}$ are the number of born fish larvae at the beginning and at the end of the period of the culture time (t). Survival (S) of eggs and larvae was also calculated as follows, $\mathrm{S}=\mathrm{Nt} / \mathrm{N}_{0}$ and mortality $\mathrm{M}=1-\mathrm{S}$, expressed as percentage. The Excel program was used. The multiple comparisons of Tukey of the growth slops were estimated.

\section{RESULTS}

Fecundity and eggs survival: Table 1 shows that there was a maximum of 1082 eggs for a female weight of $50 \mathrm{~g}$, length of 22.0 , and height of $28.8 \mathrm{~cm}$ and a minimum of 234 eggs for another of $20 \mathrm{~g}$ weight, length of 12.5 , and height of $15 \mathrm{~cm}$, with an average of 468.8 ( $\mathrm{SD} \pm 193.97$ ) eggs per fish. The relative fecundity varied from 11.44 to 21.64 eggs per gram of female with an average of $16.39(\mathrm{SD} \pm 2.79)$. The number of eggs increased 20.69 for each unit of weight (Fig. 1). The relation between number of eggs per live eggs was as follows: Number of eggs $=0.9464$ (live eggs) +6.3618 , $\mathrm{R}^{2}=0.9924, \mathrm{n}=20$. Yield survival larvae varied from 87 to $100 \%$ with an average of $96 \%$ in 60 days.

Growth: The length, height, and weight growth of the fish larvae born from November $1^{\text {st }}$ to March $15^{\text {th }}$ using the three different diets are depicted in Fig. 2. The best growth was attained with diet A, reaching $6.3 \mathrm{~cm}$ in length, $5.9 \mathrm{~cm}$ in height, and $3.62 \mathrm{~g}$ in weight, followed by diet $\mathrm{C}$ with $5.15 \mathrm{~cm}, 5.10 \mathrm{~cm}$, and $3.00 \mathrm{~g}$, respectively, and the lowest was attained with diet $\mathrm{B}$ yielding $4.81 \mathrm{~cm}, 4.79 \mathrm{~cm}$, and $2.8 \mathrm{~g}$, respectively. Tukey method confirmed that diet A was significantly different from diets B and 


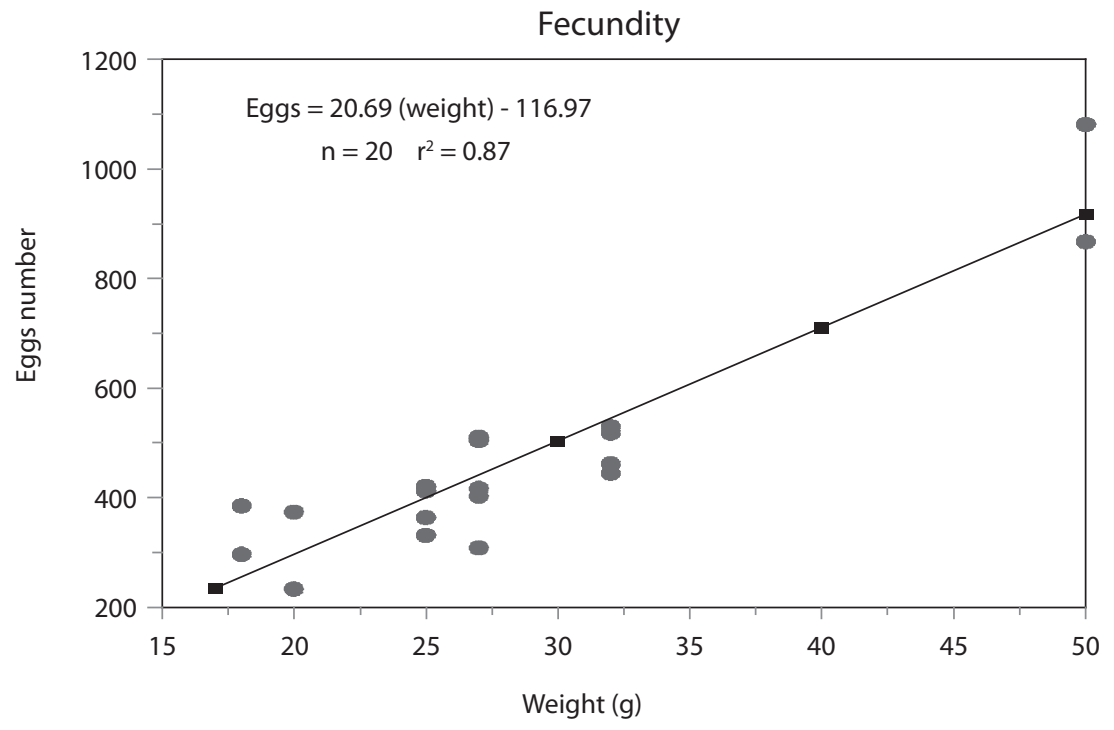

Fig. 1. Fecundity, as increase in number of eggs, for Pterophyllum scalare in this study.

Fig. 1. Fecundidad, comoincremento en número de huevos, para Pterophyllum scalare en este estudio.

$\mathrm{C}$, and this two diets themselves showed no differences in growths at $\mathrm{P}>0.50$.

In general, the greater the fish grows more eggs will be produced, as mentioned before. Although there are statistical differences in growth, it is important to note that diets A (Artemia cysts) and C (rotiferscladocerans) have a higher cost than diet $\mathrm{B}$ (balanced inert food).

Mortality: Total mortality for 2 fish lar$\mathrm{vae} / \mathrm{mL}$ in $40 \mathrm{~L}$ aquarium in 135 days using the three different diets (Fig. 3); the instantaneous total mortality rate $(\mathrm{Z})$ was $0.0026,0.0043$, and 0.0040 , respectively; with diet A the mortality was $33.8 \%$; with diet $\mathrm{C}, 43.8 \%$; and with diet $\mathrm{B}, 50.0 \%$. The best survival percentage was attained with diet A at $66.25 \%$.

\section{DISCUSSION}

Temperatures recorded in this study are suitable for culturing angelfish according to Martty \& Couto (1976). Aries (1972) recommends a temperature variation between 28 to $30^{\circ} \mathrm{C}$ for reproduction as found in this experiment.

Swingle (1961) recommended a $\mathrm{pH}$ variation between 6.5 and 9, values higher or lower prevent reproduction, although Axelrod (1976) reported that angelfish prefer a $\mathrm{pH}$ lower than 7 in the Amazon River effluents. In this paper was between 7.8 and 9.0.

The type of food has an important influence on the nutrition of fish larvae. Shirota (1970) related the size of the mouth of marine fish larvae and the prey size by an index. Lavens \& Sorgeloos (1996) and Coutteau (1996) mentioned those fish larvae of 2 to $3 \mathrm{~mm}$ preys on $300 \mu \mathrm{m}$ organisms, whereas fish larvae of 3 to $5 \mathrm{~mm}$ prey on $1 \mathrm{~mm}$ organisms. Rottmann (1989) mentioned that adults of Moina (700-1000 um) are bigger than Artemia nauplii $(500 \mu \mathrm{M})$ and three times more than rotifers. D. magna is twice as big as Moina, reason for which it is recommended to feed angelfish larvae older than 10 days.

In commercial fish culture, rotifers are the first live food given, from day 2 to 20 ; actually 

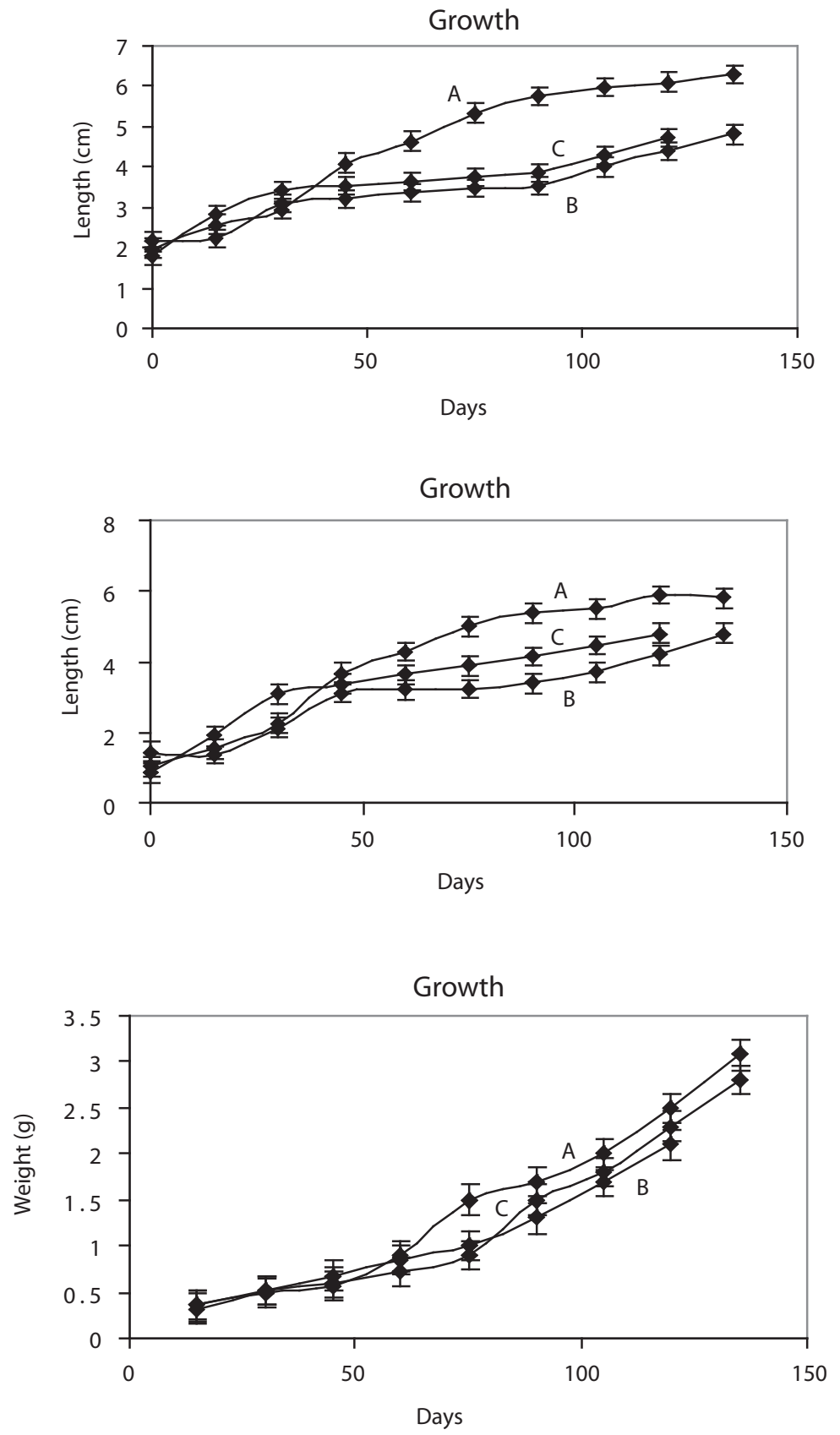

Fig. 2. Average growth in length, height, and weight for the three diets evaluated (A, B, and C). The typical errors are shown.

Fig. 2. Crecimiento promedio en longitud, altura y peso para las tres dietas evaluadas (A, B y C). Se muestran los errores típicos. 


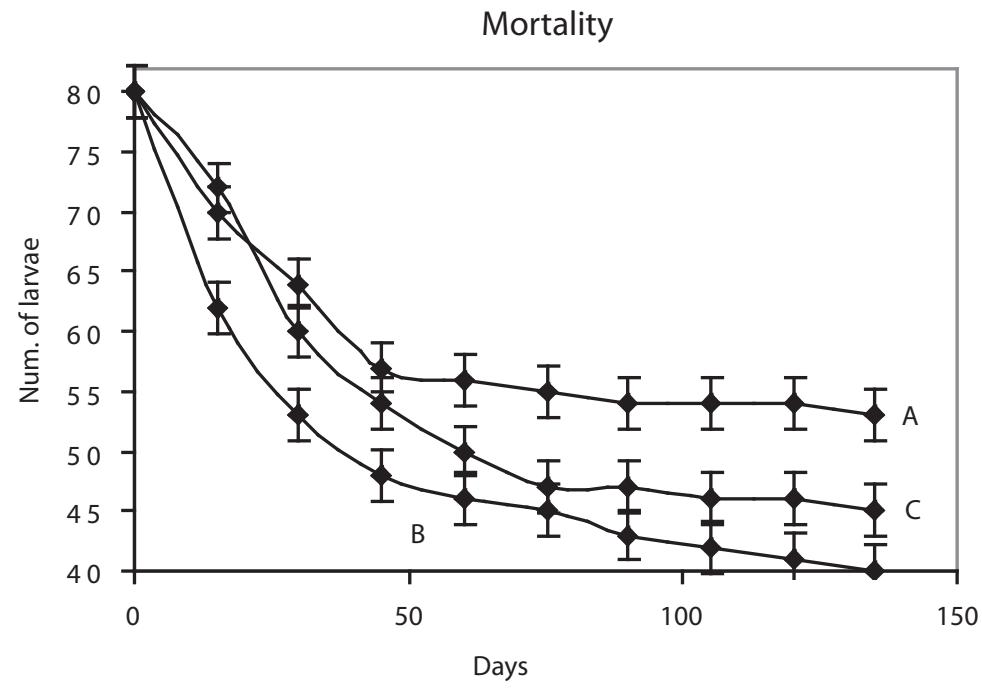

Fig. 3. Total mortality observed for the three diets used (A, B, and C). Typical errors are shown.

Fig. 3. Mortalidad total observada para las tres dietas utilizadas (A, B y C). Se muestran los errores típicos.

no other live food substitute has yet been used (Maeda \& Hino 1991).

Watanabe et al. (1983) and Tamaru et al. (1991) reported that fish larvae of 2 to $3 \mathrm{~mm}$ should be fed with rotifers during the first 30 days until they reach 7 to $10 \mathrm{~mm}$ length, and then fed them with a mix of copepods and cladocerans or Artemia nauplii. Once the larvae are $10 \mathrm{~mm}$ long, the food could be fish flour, and larvae size ends when they reach 30 to $50 \mathrm{~mm}$. Degani (1993) found that juvenile angelfish increase growth adding live Artemia to different diets with high protein, he suggest Artemia contains a micro-element that is absent in artificial food. In the present paper the best growth was using live Artemia cysts as food, also survival was higher than using artificial food.

Figueroa et al. (1977) found that angelfish fed with $D$. pulex spawned between 857 and 959 eggs, whereas with "Wardley" (balance food) spawning reached only 363 eggs. Survival was of $91 \%$ fed with $D$. pulex versus $62 \%$ fed with "Wardley". In this work a similar food as "Wardley", "Tetramin" was used. The results show less growth and higher mortality than using live food.
Knowledge on fecundity and survival are important issues for planning a good production of angelfish larvae and juveniles; besides, it is relevant to know that live food is much better for growing fish than most of the commercial balanced foods.

\section{ACKNOWLEDGMENTS}

We appreciate the technical support of A. Aguilar A., A. Nuñez P. and C. Ramírez J.

\section{RESUMEN}

Se realizaron estudios de cultivo en laboratorio del pez ángel, Pterophyllum scalare, para analizar los efectos de su dieta en la fecundidad, crecimiento y sobrevivencia en huevos y larvas por un período 135 días. Tres dietas diferentes se utilizaron A) quistes decapsulados de Artemia, B) comida comercial seca para pez, C) una mezcla de rotíferos, Brachionus plicatilis y el cladocero, Daphnia magna. La densidad inicial de larvas en acuarios de 40L fue de 100 organismos. Utilizando la dieta A, las larvas alcanzaron un peso máximo de $3.80 \mathrm{~g}$, una longitud total de $6.3 \mathrm{~cm}$ y una altura de $5.8 \mathrm{~cm}$; utilizando la dieta $\mathrm{B}$, fue de $2.80 \mathrm{~g}, 4.81 \mathrm{~cm}$ y $4.79 \mathrm{~cm}$ y con la dieta C, fue de $3.00 \mathrm{~g}, 5.15 \mathrm{~cm}$ y $5.10 \mathrm{~cm}$, respectivamente. Diferencias significativas se observaron 
entre la dieta A y las dietas B y C. La fecundidad varió de 234 a 1082 huevos en hembras de 20 y 50g, respectivamente. La sobrevivencia de los huevos varió de $87.4 \%$ a $100 \%$ y la sobrevivencia de las larvas (80 larvas por acuario de $40 \mathrm{~L}$ ) varió entre 50 y $66.3 \%$ con las dietas B y A, respectivamente. Los resultados indicaron, que la comida viva fue mejor para el crecimiento de los peces, que los alimentados con la comida comercial balanceada. La fecundidad y la sobrevivencia son factores importantes para la planificación de una buena producción del pez ángel.

Palabras clave: pez ángel, Pterophyllum scalare (Perciformes: Cichlidae), cultivo, fecundidad, crecimiento, sobrevivencia.

\section{REFERENCES}

Aries, S.S. 1972. Discus \& Scalare. Ediciones Littec, Buenos Aires, Argentine.

Axelrod, H. R. 1976. Breeding aquarium fishes. T.F.H. Publications, Neptune City, New Jersey, USA.

Axelrod, H. R, \& S.R. Shaw. 1967. Breeding aquarium fishes. T.F.H. Publications, Neptune City, New Jersey, USA.

Beverton, R.J.H. \& S.J. Holt. 1959. A review of the life span and mortality rates of fish in nature, and their relation to growth and other physiological characteristics. CIBA Found. Colloq Age. 5: 142-177.

Coutteau, P. 1996. Microalgae, p. 7-47. In Manual on the production and use of live food for aquaculture. FAO Fish. Tech. Pap. 361. FAO, Rome, Italy.

Figueroa, T.J., R.G. Berrum \& F.J. Luna. 1977. Reproducción del pez ángel Pterophyllum scalare var. Perlada, p. 109. In V Congreso Nacional de Ictiología, Mazatlán Sinaloa, Mexico.

Degani, G. 1993. Growth and body composition of juveniles of Pterophyllum scalare (Lichtenstein) (Pisces: Cichlidae) at different densities and diets. Aquaculture and Fisheries Management 24: 725-73.

Lavens, P. \& P. Sorgeloos. 1996. Manual on the production, and use of live food for aquaculture. FAO, Fish. Tech. Pap. 361. Rome, Italy.
Maeda, M. \& A. Hino. 1991. Environmental management for mass culture of the rotifer, Brachionus plicatilis, p.125-134. In Rotifer and micro-algae culture system. W. Fulks \& K. L. Main (eds.). Proceedings of a US-Asia Workshop. The Oceanic Institute, Honolulu, Hawaii, USA.

Martty, A.H. 1977. Alimentación de peces ornamentales. Albatros, Buenos Aires, Argentine.

Martty, A.H. \& D.D. Coutto. 1976. Peces tropicales y el novicio. Albatros, Buenos Aires, Argentine.

Pérez, S.L.A. 1984. Piscicultura. El manual moderno.

Reyes-Bustamante, H. 1999. Evaluación y optimización de la producción de microalgas del rotífero Brachionus plicatilis y del cladócero, Daphnia magna bajo diferentes condiciones de cultivo. Tesis Doctoral. Colegio de Ciencias y Humanidades, Unidad Académica de los Ciclos Profesionales y de Posgrado, Universidad Nacional Autónoma de México, Mexico.

Ricker, W.E. 1975. Computation, and interpretation of biological statistics of fish populations. Bull. Fish. Res. Canada 191.

Rottmann, R.W. 1989. Daphnia culture. Florida. Aquarium Farms Inc. 1: 99-123.

Shirota, A. 1970. Studies on the mouth size of fish larvae. Bull. Japan. Soc. Sci. Fish. 36: 353-368.

Swingle, H.S. 1961. Relationships of $\mathrm{pH}$ of pond waters to their suitability for fish culture. Proceed. Pac. Sci. Cong. 9: 72-75.

Tamaru, C.S., Lee, C. \& H. Ako. 1991. Improving the larval rearing of striped mullet (Mugil cephalus) by manipulating quantity and quality of the rotifer, Brachionus plicatilis, p. 89-104. In Rotifer and micro-algae culture system, W. Fulks \& K. L. Main (eds.). Proceedings US-Asia Works, The Oceanic Institute, Hawaii, USA.

Watanabe, T., C. Jitajima \& S. Fujita. 1983. Nutritional value of live food organisms used in Japan for mass culture of fish. Rev. Aqua. 34: 115-143. 